\title{
Vitamin D receptor gene polymorphisms in breast cancer
}

\author{
Nur Buyru ${ }^{1}$, Ayda Tezol ${ }^{1}$ \\ Elif Yosunkaya-Fenerci ${ }^{1}$ and Nejat Dalay ${ }^{2,3}$ \\ ${ }^{1}$ Cerrahpasa Medical Faculty \\ Department of Medical Biology \\ ${ }^{2}$ Oncology Institute, Istanbul University \\ Istanbul, Turkey \\ ${ }^{3}$ Corresponding author: Tel, 90-212-5313100; \\ Fax, 90-212-5348078; E-mail, ndalay@yahoo.com
}

Accepted 1 December 2003

Abbreviation: VDR, vitamin D receptor

\begin{abstract}
Breast cancer is the leading cause of cancer death among women around the world and its incidence is annually increasing. The vitamin $D$ receptor (VDR) gene is a member of the nuclear receptor superfamily, which is expressed in breast tissue and known to modulate the rate of cell proliferation. Association between the VDR gene polymorphisms and cancer development has been suggested by several studies. However, the relationship between VDR polymorphisms and breast cancer is controversial and has not been confirmed by all studies. The purpose of this study was to investigate the genotype frequencies and association of the VDR Bsm I and Taq I polymorphisms with breast cancer in Turkish patients. In this study, 78 patients with breast cancer and 27 healthy individuals were enrolled. The prevalence of the VDR Taq I and Bsm I alleles and the genotype frequencies in patients with breast cancer was similar to that in the normal population. Our data indicate that no significant differences exist between the patients and control subjects.
\end{abstract}

Keywords: breast cancer; polymorphism; VDR

\section{Introduction}

Breast cancer is a heterogeneous disease regarding its morphology, invasive behavior, metastatic capacity, hormone receptor expression and clinical outcome. $10-15 \%$ of breast cancer cases have some family history of the disease but only $5 \%$ can be explained by rare highly penetrant mutations in genes such as BRCA1 and BRCA2. Although some of the familial risk may be due to the shared environment, there may be other common, low-penetrance genetic variants which alter the predisposition to breast cancer. Endogenous hormone exposure is known to affect breast cancer susceptibility and genes responsive to such hormones are plausible candidates for predisposition genes (Pharoah et al., 1997).

The steroid hormone 1,25-dihydroxyvitamin $D_{3}$ $\left(1,25(\mathrm{OH})_{2} \mathrm{D}_{3}\right)$ binds the vitamin $\mathrm{D}$ receptor (VDR) and the ligand/receptor complex regulates transcription of the genes involved in cell cycle, apoptosis and differentiation (Simboli-Campbell et al., 1996). In the normal mammary gland, $1,25(\mathrm{OH})_{2} \mathrm{D}_{3}$ may function to regulate calcium transport during lactation or may act in concert with other hormones to maintain mammary cell differentiation and milk protein production (Bhattacharjee et al., 1987; Mezzetti et al., 1988). Dysregulation of VDR-mediated gene expression would alter mammary gland development or function and possibly predispose cells to transformation (Buras et al., 1994).

The VDR gene is located on the long arm of chromosome $12(12 q 12-14)$ and is composed of 10 exons, the first of which is not transcribed (Tokita et al., 1996). A series of common polymorphisms in the vitamin $D$ receptor gene were recently reported be associated with both circulating levels of active vitamin $D$ and in vitro measures of gene expression (Morrison et al., 1992). Three of these polymorphisms can be distinguished by digestion with restriction enzymes (Hustmyer et al., 1993). The presence or absence of a restriction site defines the specific allele. None of these polymorphisms change the translated protein. The Bsm I and Apa I polymorphisms are located in intron 8 of the VDR gene (Baker et al., 1988; Morrison et al., 1994). The Taq I polymorphism is located in exon 9 but leads to a silent codon change, with ATT and ATC both coding for isoleucine (Farrow, 1994).

Allelic variations of the VDR gene have been associated with the risk of osteoporosis in postmenopausal women (Jorgensen et al., 1996) and prostate cancer in men (Ingles et al., 1997). Presence of the tt genotype has been found to be less frequent in prostate cancer patients. Therefore, it has been suggested that the $\mathrm{t}$ allele might protect against prostate cancer (Taylor et al., 1996). In breast cancer, low vitamin $D$ levels in serum are correlated with disease progression and bone metastases, a situation also 
noted in prostate tumors and suggesting involvement of the VDR gene in breast carcinogenesis (Mawer et al., 1997). However, the relationship between VDR polymorphisms and breast cancer is controversial (Ingles et al., 2000; Hou et al., 2002).

The purpose of this study was to investigate the association of the VDR gene Taq I and Bsm I polymorphisms with breast cancer.

\section{Materials and Methods}

Blood samples were obtained from 78 breast cancer patients and 27 healthy subjects. DNA for molecular analysis was isolated using standard procedures.

PCR amplification followed by restriction enzyme digestion was used to investigate the two (Taq $I$ and Bsm I) polymorphisms at the VDR locus using 10 pmol each of the forward and reverse primers and $100 \mathrm{ng}$ of genomic DNA. To analyze the intron $8 \mathrm{Bsm}$ I polymorphism, we used the primer pair 5'CAACAAGACTACAAGTACCGCGTCAGTGA3', 5'AACCAGCGGGAAGAGGTCAAGGG3' and 30 amplification cycles of denaturation at $94^{\circ} \mathrm{C}$ for $30 \mathrm{~s}$, annealing at $57^{\circ} \mathrm{C}$ for $30 \mathrm{~s}$ and extension at $72^{\circ} \mathrm{C} 30 \mathrm{~s}$. Final extension was allowed to proceed for $5 \mathrm{~min}$ at $72^{\circ} \mathrm{C}$. In order to investigate the Taq I polymorphism, the primer pair used was 5'CAGAGCATGGACAGGGAGCAA3', 5'GCAACTCCTCATGGCTGAGGTTCT3' with 30 cycles of denaturation at $94^{\circ} \mathrm{C}$ for $30 \mathrm{~s}$, annealing at $55^{\circ} \mathrm{C}$ for $30 \mathrm{~s}$ and extension at $72^{\circ} \mathrm{C}$ for $30 \mathrm{~s}$, with a final extension for $5 \mathrm{~min}$ at $72^{\circ} \mathrm{C}$. Amplification of the intron 8 and exon 9 polymorphic regions yielded products of $825 \mathrm{bp}$ and $740 \mathrm{bp}$, respectively.

$10 \mu \mathrm{l}$ of amplification product was then digested with $10 \cup \operatorname{Taq} /$ (MBI, Fermentas, Lithuania) or 2.5 $\mathrm{U}$ of Bsm I (Promega) for at least $3 \mathrm{~h}$ at $65^{\circ} \mathrm{C}$ and $37^{\circ} \mathrm{C}$, respectively. The digestion products were subjected to electrophoresis on $2 \%$ agarose gels for 1

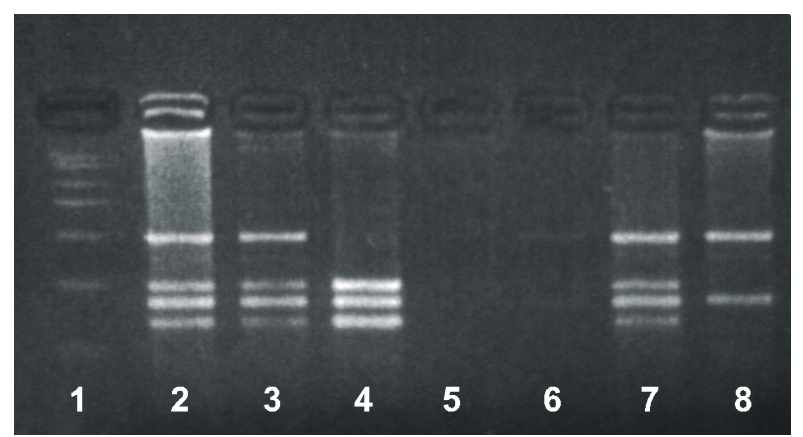

Figure 1. Ethidium bromide-stained $2 \%$ agarose gel showing PCR products of the VDR gene after digestion with Taq I. Lanes 2, 3 and $7 ; \mathrm{Tt}$, lane 4; tt and lanes 6 and 8; TT genotypes. Lane 1; molecular weight marker, lane 5 ; no template control. $\mathrm{h}$ at $100 \mathrm{~V}$. The gels were evaluated in the video gel documentation system (Vilber-Lourmat, Cedex, France) using the BIOPROFIL 1D software and printed using the SONY UP 890 video graphic printer.

The $\chi^{2}$ test was used to evaluate the variations of the genotype frequencies among the cases and the controls. The Odds ratios and the confidence intervals were calculated as an estimate of the relative risk. SPSS 7.5 professional statistics analysis (SPSS, Chicago) was used for the statistical calculations.

\section{Results}

The Bsm I and Taq I polymorphisms in the VDR gene were investigated by PCR-RFLP analysis in breast cancer patients. We also genotyped 27 healthy individuals as the control group. The frequencies of the alleles and the genotypes were in Hardy-Weinberg equilibrium among the patients and the controls.

The size of the PCR product for the Bsm I polymorphism was $825 \mathrm{bp}$. Following digestion two restriction fragments of $650 \mathrm{bp}$ and $175 \mathrm{bp}$ were observed for bb homozygotes. A single $825 \mathrm{bp}$ band was obtained for BB homozygotes. Heterozygote individuals displayed all three bands (Figure 1).

$57.7 \%$ of the patients were heterozygous for the Bsm I polymorphism, $19.3 \%$ were homozygous BB and $23 \%$ were homozygous bb. The respective frequencies in the control group were $63 \%, 18.5 \%$ and $18.5 \%$. These frequencies are not significantly different from those in the breast cancer patients $\left(\chi^{2}=\right.$ $0.28997, P=0.86, d f=2)$. The frequencies of the $B$ and $b$ alleles were equal in both groups. The allelic and genotypic frequencies in the patients and controls for the Bsm I polymorphism are shown in Table 1. The size of the reaction product for the Taq I polymorphism was $740 \mathrm{bp}$, which on digestion with

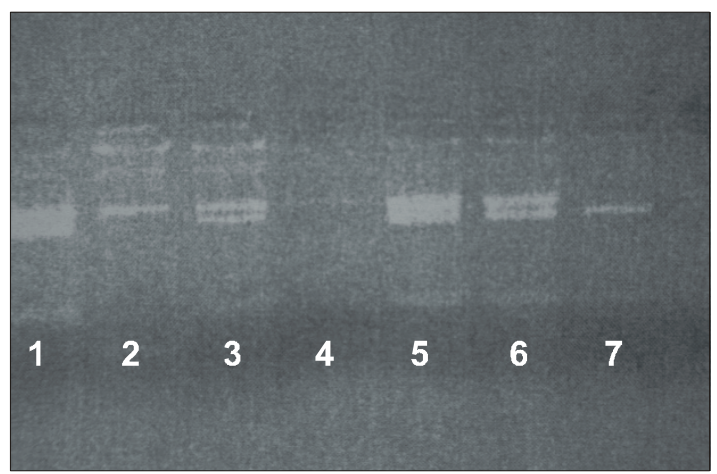

Figure 2. Detection of Bsm I polymorphism by PCR-RFLP. The upper bands represent allele $B$, the lower bands allele $b$. Lanes 1,3 , 5 and $6 \mathrm{Bb}$ heterozygotes; lanes 2 and $4 \mathrm{BB}$ homozygotes; and lane $7 \mathrm{bb}$ homozygote. 
Table 1. Genotypic and allelic requencies of the Taq I polymorphism.

\begin{tabular}{cccc}
\hline VDR Tagl genotwdes & Breast cancer $n=78(\%)$ & Controls $n=27(\%)$ & OR (95\% Cl) \\
\hline TT & $26(33.3 \%)$ & $4(14.8 \%)$ & $1.04(0.267-4.489)$ \\
Tt & $44(56.4 \%)$ & $20(74.0 \%)$ & $\begin{array}{c}1.486(0.796-2.771) \\
(0.05\end{array}$ \\
tt & $8(10.3 \%)$ & $3(11.1 \%)$ & 1 (reference) \\
Alleles & & & \\
$T$ & $96(61.5 \%)$ & $28(52.0 \%)$ & \\
$t$ & $60(38.4 \%)$ & $26(48.0 \%)$ & \\
\hline
\end{tabular}

Table 2. Genotypic and allelic frequencies of the Bsm I polymorphism.

\begin{tabular}{cccc}
\hline VDR Bsml genotvoes & Breast cancer $n=78(\%)$ & Controls $n=27(\%)$ & OR (95\% Cl) \\
\hline BB & $15(19.2 \%)$ & $5(18.5 \%)$ & $\begin{array}{c}0.758(0.250-2.294) \\
P \geq 0.05\end{array}$ \\
Bb & $45(57.7 \%)$ & $17(62.9 \%)$ & $\begin{array}{c}0.926(0.498-1.722) \\
P \geq 0.05\end{array}$ \\
bb & $18(23.0 \%)$ & $5(18.5 \%)$ & 1 (reference) \\
Alleles & & & \\
B & $75(48.1 \%)$ & $27(50.0 \%)$ & \\
b & $81(51.9 \%)$ & $27(50.0 \%)$ & \\
\hline
\end{tabular}

Taq I yielded three distinct patterns. Restriction of neither allele (TT) results in two fragments of $495 \mathrm{bp}$ and 245 bp. Restriction of both alleles results in three fragments of $290 \mathrm{bp}, 245 \mathrm{bp}$ and $205 \mathrm{bp}$. Restriction of one allele only yields all four fragments of $495 \mathrm{bp}$, $290 \mathrm{bp}, 245$ bp and 205 bp. The 245 bp fragment is present among all genotypes, and is created by a nonpolymorphic $T a q$ / site within the amplification product (Figure 2).

Our study revealed no significant differences in the prevalence of the alleles and the genotypes in the patients and the control group. In our study group, the genotype frequencies were $33.3 \%$ vs. $14.8 \%$ TT, $56.4 \%$ vs. $74.0 \%$ Tt and $10.3 \%$ vs. $11.2 \%$ tt in the breast cancer patients and the controls, respectively. We observed the $t$ allele in $38.5 \%$ and $48 \%$, and the $\mathrm{T}$ allele in $61.5 \%$ and $52.0 \%$ in the patients and the control group, respectively. $\left(\chi^{2}=3.37, P=0.18, d f=\right.$ 2 ). The frequencies of $T a q /$ genotypes and alleles were not significantly different in the patients and the controls $\left(\chi^{2}=1.56, P=0.2, d f=2\right)$ (Table 2).

Our data indicate that, polymorphisms in the VDR gene do not affect breast cancer susceptibility.

\section{Discussion}

There are substantial numbers of reports that have investigated candidate genes for breast cancer susceptibility. Breast cancer risk is strongly related to endogenous hormone exposure and genes responsive to such hormones are therefore plausible candidates for being susceptibility genes. The VDR is a member of the steroid hormone receptor superfamily and regulates gene transcription through interaction with hormone response elements in the promoter region of target genes (Christakos et al., 1996). The presence of VDR in breast cancer has been documented both in cell lines (Demirpence et al., 1994; James et al., 1994; Vink-van Wijngaarden et al., 1994; LoveSchimenti et al., 1996) and in tumor samples (Swedish Breast Cancer Cooperative Group, 1996). Both the $5^{\prime}$ and 3 'ends of the VDR gene are polymorphic. A polymorphism in the first of the two possible translation start codons produces variants differing in size and activity (Miyamoto et al., 1997). Allelic variation in the $3^{\prime}$ end of the VDR gene, although less clearly related to its function, appears to have phenotypic consequences for the calcium (Dawson-Hughes et al., 1995; Wishart et al., 1997) and vitamin D metabolism 
(Morrison et al., 1994; Ma et al., 1998), bone mineral density (Morrison et al., 1998) and osteoporosis (Ingles et al., 1997a), while the 5' polymorphisms are involved in peak bone density (Harris et al., 1997).

The Taql polymorphisms have been investigated most frequently in prostate cancer and presence of the $T$ alleles has been associated with increased prostate cancer risk. However, the issue is still controversial since there are also reports that do not confirm such an association. Studies investigating VDR polymorphisms in breast cancer are rare and inconsistent. Two studies (Ruggiero et al., 1998; Ingles et al., 2000) have revealed a 4 -fold higher risk of metastatic spread in breast cancer patients carrying the Bsml restriction site in the VDR gene. Bretherton-Watt et al. (2001) also reported an association between the bb genotype and grade II and III tumors. On the other hand, an association between the bb allele and breast cancer has been refuted in other reports (Mocherla et al., 1997; Gross et al., 1998; Hou et al., 2002). In our study, no difference in the frequency of the b allele was observed in the breast cancer group. Statistical analysis did not reveal any significant difference in the prevalance of the Bsml polymorphism in breast cancer patients when compared with controls. Genotype frequencies were also similar in women with breast cancer and in the control population. Our data are consistent with reports on breast (Schndorf et al., 2003) and prostate cancer (Ma et al., 1998; Suzuki et al., 2003).

It has been reported that individuals homozygous for the $t$ allele are significantly underrepresented among prostate cancer patients, illustrating a protective role for the $t$ allele in prostate carcinogenesis (Taylor et al., 1996; Hamasaki et al., 1999). However, these findings have not been corroborated in later studies (Blazer et al., 2000; Habuchi et al., 2000). Regarding breast cancer, both a tendency towards a decreased mortality rate in tt homozygote breast cancer patients (Lundin et al., 1999) as well as decreased risk in patients with the TT genotype (Schöndorf et al., 2003) have been reported. In our study, investigation of the Taql site between affected and control individuals, however, did not reveal a difference between the frequencies of the genotypes. Lack of association between the Taql alleles and breast cancer is in agreement with earlier (Dunning et al., 1999; Lundin et al., 1999) and recent reports (Hou et al., 2002; Newcomb et al., 2002; Schndorf et al., 2003). The genotype frequencies in our breast cancer group are in concordance with the reports in the literature. However, the frequency of tt homozygotes in our control group is lower than reported by Schöndorf et al., 2003. This difference may be due to the ethnic origin of populations.

The frequencies of $\mathrm{T}$ and $\mathrm{t}$ alleles were $61.5 \%$ and
$38.5 \%(P=0.058)$ in our patient group, while Curran et al. have reported allele frequencies of $64.0 \%$ and $36.0 \%(P=0.053)$ and concluded that this indicated a significant difference between the patients and the control groups. However, in our opinion statistical significance at the 0.05 level provides no evidence that this polymorphism is associated with incidence of breast cancer.

In conclusion, we have not found any evidence that differences in the oncogenic properties of the VDR gene Taql and Bsml alleles could confer a genetic predisposition to breast carcinogenesis. Comparing the patient group with the controls revealed no significantly increased risk for breast cancer patients carrying the TT or bb genotypes.

\section{Acknowledgement}

This study was supported by the Istanbul University Research Fund, Project Nrs: 1639/30042001 and BYP. $68 / 26082002$.

\section{References}

Baker AR, Donnel DP, Hughes M, Crisp TM, Mangelsdorf DJ, Haussler MR, Pike JW, Shine J, O'Malley BW. Cloning and expression of full length cDNA encoding vitamin D receptor. Proc Natl Acad Sci 1988;85:3294-8

Bhattacharjee M, Wientroub S, Vonderhaar BK. Milk protein synthesis by mammary glands of vitamin D-deficient mice. Endocrinology 1987;121:865-74

Blazer DG 3rd, Umbach DM, Bostick RM, Taylor JA. Vitamin $D$ receptor polymorphisms and prostate cancer. Mol Carcinog 2000;27:18-23

Bretherton-Watt D, Given-Wilson R, Mausi JL, Thomas V, Carter N, Colston KW. Vitamin D receptor gene polymorphisms are associated with breast cancer risk in a UK Caucasian population. $\mathrm{Br} \mathrm{J}$ Cancer 2001;85:171-5

Buras RR, Schumaker LM, Davoodi F, Bienner RV, Shabahong M, Nauta RJ, Evans RTS. Vitamin D receptors in breast cancer cells. Breast Cancer Res Treat 1994;31: 191-202

Christakos S, Raval-Pandya M, Wernjy RP, Yang W. Genomic mechanisms involved in the pleitropic actions of 1,25-dihydroxyvitamin $D_{3}$. Biochem $J$ 1996;316:361-71

Curran JE, Vaughan T, Lea RA, Weinstein SR, Morrison NA, Griffiths LR. Association of a vitamin D receptor polymorphism with sporadic breast cancer development. Int J Cancer 1999;83:723-6

Dawson-Hughes B, Harris SS, Finneran S. Calcium absorption on high and low calcium intakes in relation to vitamin D receptor genotype. J Clin Endocrinol 1995;80: 3657-61

Demirpence E, Balaguer P, Trousse F, Nicolas JC, Pons $M$, Gagne D. Antiestrogenic effects of all-trans-retinoic 
acid, and 1,25-dihydroxyvitamin $D_{3}$ in breast cancer cells occur at the estrogen response element level but through different molecular mechanisms. Cancer Res 1994;54: 1458-64

Dunning AM, McBride S, Gregory J, Durocher F, Foster NA, Healey CS, Smith N, Pharoah PD, Luben RN, Easton DF, Ponder BA. No association between androgen or vitamin $D$ receptor gene polymorphisms and risk of breast cancer. Carcinogenesis 1999;20:2131-5

Farrow $S$. Allelic variation and the vitamin $D$ receptor. Lancet 1994;343:1242

Gross C, Musiol IM, Eccleshall TR, Malloy PJ, Feldman $D$. Vitamin $D$ receptor gene polymorphisms: analysis of ligand binding and hormone responsiveness in cultured skin fibroblasts. Biochem Biophys Res Commun 1998;242: 467-73

Habuchi T, Suzuki T, Sasaki R, Wang L, Sato K, Satoh S, Akao T, Tsuchiya N, Shimado N, Wada Y, Koizumi A, Chihara J, Ogawa $\mathrm{O}$, Kato $\mathrm{T}$. Association of vitamin $\mathrm{D}$ receptor gene polymorphism with prostate cancer and benign prostatic hyperplasia in Japanese population. Cancer Res 2000;60:305-8

Hamasaki T, Inatomi H, Katoh T, Ikuyama T, Matsumoto T. Clinical and pathological significance of vitamin $D$ receptor gene polymorphism for prostate cancer which is associated with a higher mortality in Japanese. Endocr $\mathrm{J}$ 2001;48:543-9

Harris SS, Eccleshall TR, Gross C, Dawson-Hughes B, Feldman D.The vitamin receptor start codon polymorphism (Fokl) and bone mineral density in premenopausal American black and white women. J Bone Miner Res 1997; 12:1043-8

Hou MF, Tien YC, Lin GT, Cheen CJ, Liu CS, Lin SY, Huang TJ. Association of vitamin D receptor gene polymorphism with sporadic breast cancer in Taiwanese patients. Breast Cancer Res Treat 2002;74:1-7

Hustmyer FG, DeLuca HF, Peacock M. Apa I, Bsm I, Eco $R V$, and $T a q$ I polymorphism at the vitamin $D$ receptor gene locus in Caucasians, Blacks and Asians. Hum Mol Genet 1993;2:487

Ingles SA, Haile R, Henderson B, Kolonel L, Coetzee G. Association of vitamin $D$ receptor genetic polymorphism with breast cancer risk in African-American and Hispanic Women. In A. W. Norman, R. Bouillon and M. Thomasset (eds) Vitamin D: chemistry, biology and clinical applications of the steroid hormone. University of California, Los Angeles 1997a;811-2

Ingles SA, Ross RW, Yu MC, Irvine RA, LaPera G, Haile RW, Coetzee GA. Association of prostate cancer risk with vitamin $D$ receptor genetic polymorphisms. J Natl Canc Inst (Bethesda) 1997b;89:166-70

Ingles SA, Garcia DG, Wang W, Nieters A, Hendersen BE, Kolonel LN, Haile RW, Coetzee GA.Vitamin D genotype and breast cancer in latinas (United States). Cancer Cause Control 2000;11:25-30

James SY, Mackay AG, Binderup L, Colston KW. Effects of a new synthetic vitamin $D$ analogue, EB 1089, on the oestrogen-responsive growth of human breast cancer cells.

\section{J Endocrinol 1994:141:555-63}

Jorgensen HL, Scholler J, Sand JC, Bjuring M, Hassager $C$, Christiansen $C$. Relation of common allelic variation at vitamin $D$ receptor locus to bone mineral density and postmenopausal bone mass: Cross sectional and longitudinal population study. $\mathrm{Br}$ Med J 1996;313:586-90

Love-Schimenti CD, Gibson DFC, Ratnam AV, Bikle DD. Antiestrogen potentiation of antiproliferative effects of vitamin $D_{3}$ analogues in breast cancer cells. Cancer Res 1996;56:2787-94

Lundin AC, Söderkvist $P$, Eriksson B, Bergman-Jungeström $M$, Wingren $S$, South-East Sweden Breast Cancer Group. Association of breast cancer progression with a vitamin $D$ receptor gene polymorphism. Cancer Res 1999;59:2332-4

Ma J, Stampfer MJ, Gann PH, Hough HL, Giovannucci E, Kelsey KT, Hennekens $\mathrm{CH}$, Hunter DJ. Vitamin D receptor polymorphisms, circulating vitamin D metabolites, and risk of prostate cancer in United State physicians. Cancer Epidemiol Biomarkers Prev 1998;7:385-90

Mawer EB, Walls J, Howell A, Davies M, Ratcliffe WA, Bundred NJ. Serum 1,25-dihydroxyvitamin D may be related inversly to disease activity in breast cancer patients with bone metastases. J Clin Endocrinol Metab 1997;82: 118-22

Mezzetti G, Monti MG, Pernecco-Caoolo L, Piccinini G, Moruzzi MS. 1,25-Dihydroxycholecolciferol-dependent calcium uptake by mouse mammary gland in culture. Endocrinology 1988;122:389-94

Miyamoto K, Kesterson RA, Yamamoto $H$, Taketani $Y$, Nishiwaki E, Tatsumi S, Inoue Y, Morita K, Takeda E, Pike JW. Structural organization of the human vitamin D receptor chromosomal gene and its promoter. Mol Endocrinol 1997;11:1165-79

Mocharla H, Butch AW, Pappas AA, Flick JT, Weinstein RS, De Togni P, Jilka RL, Roberson PK, Parfitt AM, Manolagas SC. Quantification of vitamin D receptor mRNA by competitive polymerase chain reaction in PBMC: lack of correspondence with common allelic variants. J Bone Miner Res 1997;12:726-33

Morrison N. Vitamin D receptor gene variants and osteoporosis: a contributor to the polygenic control of bone density. In: Feldman D, Glorieux FH, Pike JW, eds. Vitamin D. San Diego, CA: Academic Press 1998;713-32

Morrison NA, Yeoman R, Kelly PJ, Eisman JA. Contribution of trans-acting factor alleles to normal physiological variability: vitamin $\mathrm{D}$ receptor gene polymorphisms and circulating osteocalcin. Proc Natl Acad Sci USA 1992;89: $6665-9$

Morrison NA, Qi JC, Tokita A, Kelly PJ, Crofts L, Nguyen TV, Sambrook PN, Eisman JA. Prediction of bone density from vitamin D receptor alleles. Nature 1994;367:284-7

Newcomb PA, Kim H, Trentham-Dietz A, Farin F, Hunter $D$, Egan KM. Vitamin $D$ receptor polymorphism and breast cancer risk. Cancer Epidemiol Biomarkers Prev 2002;11: 1503-4

Pharoah PDP, Day NE, Duffy S, Easton DF, Ponder BAJ. Family history and the risk of breast cancer: a systematic 
review and meta-analysis. Int J Canc 1997;71:800-9

Ruggiero M, Pacini S, Aterini S, Fallai C, Ruggiero C, Pacini $P$. Vitamin $D$ receptor gene polymorphism is associated with metastatic breast cancer. Oncol Res 1998;10: 43-6

Schöndorf T, Eisberg C, Wassmer G, Warm M, Becker $M$, Rein DT, Göhring UJ. Association of the vitamin D receptor genotype with bone metastasis in breast cancer patients. Oncology 2003;64:154-9

Simboli-Campbell M, Narvaez CJ, Tenniswood M, Welsh J. 1,25-Dihydroxyvitamin $D_{3}$ induces morphological and biochemical markers of apoptosis in MCF-7 breast cancer cells. J Steroid Biochem Mol Biol 1996;58:367-76

Suzuki K, Matsui H, Ohtake N, Nakata S, Takei T, Koike $H$, Nakazato $H$, Okugi $H$, Hasumi M, Fukabori $Y$, Kurokawa $\mathrm{K}$, Yamanaka $\mathrm{H}$. Vitamin $\mathrm{D}$ receptor gene polymorphism in familial prostate cancer in a Japanese population. Int J Urol 2003;10:261-6

Swedish Breast Cancer Cooperative Group. Randomized trial of two versus five years of adjuvant tamoxifen for postmenopausal early stage breast cancer. J Natl Cancer Inst 1996;88:1543-9

Taylor JA, Hirvonen A, Watson M, Pittman G, Mohler JL, Bell DA. Association of prostate cancer with vitamin $D$ receptor gene polymorphism. Cancer Res 1996;56:4108-10

Tokita A, Matsumoto $H$, Morrison MA, Tawa T, Miura $Y$, Fukamauchi $K$, Mitsuhashi $N$, Irimoto $M$, Yamamori $S$, Miura M, Watanabe T, Kuwabara Y, Yabuta K, Eisman JA. Vitamin $D$ receptor alleles, bone mineral density and turnover in premenopausal Japanese women. J Bone Miner Res 1996;11:1003-9

Vink-van Wijngaarden T, Pols HAP, Buurman CJ, van den Bernd GJCM, Dorssers LCJ, Birkenhager JC, van Leeuwen JPTM. Inhibition of breast cancer cell growth by combined treatment with vitamin $D_{3}$ analogues and tamoxifen. Cancer Res 1994;54:5711-7

Wishart JM, Horowitz M, Need AG, Scopacasa F, Morris HA, Clifton PM, Nordin BE. Relations between calcium intake, calcitriol, polymorphisms of the vitamin $D$ receptor gene, and calcium absorption in premenopausal women. Am J Clin Nutr 1997;65:798-802 